\title{
A NEW SPECIES AND A NEW RECORD OF THE GENUS MACROGLENES WESTWOOD (HYMENOPTERA: PTEROMALIDAE) FROM INDIA
}

\author{
T.C. Narendran ${ }^{1}$, P.M. Sureshan ${ }^{2}$, P. Girish Kumar ${ }^{3}$ and S. Santhosh ${ }^{3}$ \\ ${ }^{1,3}$ Systematic Entomology Laboratory, Department of Zoology, University of Calicut, Malappuram District, Kerala 673635, India \\ ${ }^{2}$ Zoological Survey of India, Western Regional Station, Pune, Maharashtra 411044, India \\ Email: ${ }^{1}$ drtcnarendran@yahoo.com
}

\begin{abstract}
The genus Macroglenes Westwood is reported for the first time from India with the description of a new species from Kerala. Its distinguishing characters from other species are also discussed.

KEYWORDS

Hymenoptera, Kerala, Macroglenes sivani Narendran and Sureshan, sp. nov., new species, new record, Pteromalidae, India.

AbBreVIATIONS

F1-F5 - Funicular segments 1 to 5; OOL - Ocellocular distance; POL - Postocellar distance; SMV - Submarginal vein; MV Marginal vein; PMV - Postmarginal vein; STV - Stigmal vein; DZUC - Department of Zoology, University of Calicut; ZSIC Western Ghats Regional Station of Zoological Survey of India, Kozhikode
\end{abstract}

The genus Macroglenes was described by Westwood (1832) from Europe. Graham (1969) dealt with the species of North Western Europe under the generic name Pirene Haliday. Later, Boucek (1988) redefined the genus giving its junior synonyms including Pirene Haliday. According to Boucek (1988) the members of the genus Macroglenes are distributed in Europe (11 species), East Asia (2 species), North America (2 species) and Australia (at least 12 undescribed species). In this paper we report the presence of this genus for the first time in India based on specimens collected from the Kerala state, which proved to be an undescribed species. The same is described below.

The types of the new species described here are deposited in the Narendran Collection of the Systematic Entomology Laboratory of DZUC, but eventually will be transferred to ZSIC.

Macroglenes sivani Narendran and Sureshan, sp. nov. (Figs.1 - 4)

\section{Material examined}

Holotype: Female, 19.ii.2003, Kottiyur forests $\left(75^{0} 55^{\prime} \mathrm{E} \& 11^{0} 52^{\prime} \mathrm{N}\right)$ Kannur, Kerala, coll. T.C. Narendran and party, DZUC. Paratype: 1Male, 8.i.2004, Vandiperiyar $\left(77^{\circ} 05^{\prime} \mathrm{E} \& 09^{\circ} 32^{\prime} \mathrm{N}\right)$ Idukki, Kerala, coll. T.C. Narendran and party, DZUC.

\section{Distribution}

India: Kottiyur forests (Kannur) and Vandiperiyar High ranges (Idukki) of Kerala. The specimens were collected by sweep net method.

\section{Etymology \\ Arbitrary combination of letters.}

\section{Diagnostic characters}

Female: Length $1.36 \mathrm{~mm}$. Black, shiny; eyes brownish-red with margins yellowish-brown; ocelli pale reflecting yellow. Antenna, forelegs and mid legs brown with tarsi paler; hind leg blackishbrown with knees, apex of tibia and tarsi paler. Gaster blackishbrown with hypopygium and ovipositor sheath brown. Wings hyaline with veins fuscous, pilosity brown. Pubescence on body dirty white.

Head: Width in anterior view $1.21 \mathrm{x}$ its length; width in dorsal view $3.2 x$ its median length. Edge of occiput just behind the ocelli rather sharp. Eye length $1.43 \mathrm{x}$ its width in side view, sparsely pilose. POL $1.7 x$ OOL. Malar space more than $0.35 x$ eye length. Antenna with scape shorter than an eye, $4.7 \mathrm{x}$ as long as broad; pedicellus $1.67 \mathrm{x}$ as long as broad, a little shorter than combined length of 3 anelli+F1+F2 (15:16.1); F1 transverse, anelliform; F2 1.5x as wide as its length; F3 a little longer than $\mathrm{F} 1 ; 1.33 \mathrm{x}$ as broad as long; clava subequal in length to combined length of anelli+F1+F2, 2.6x as long as its width; flagellum clothed with rather short hairs.

Mesosoma: Not depressed, arched dorsally. Pronotum reticulate, sparsely pilose; mesoscutum and scutellum with delicate, faint though distinct reticulations. Notauli complete; mesoscutum with three pairs of setae; mesoscutum $2.48 \mathrm{x}$ as broad as long; scutellum 1.3x as long as its width; frontal groove distinct but weak; six setae present, two pairs on scutellum, and one on each axilla; dorsellum semicircular and smooth. Propodeum slightly slanting, gently declining, smooth without a median carina; spiracle circular close to metanotum, callus with one bristle on posterior part and one on anterior part on each side. Legs with a well developed and regular pectin on hind tibia, extending over whole length of hind tibia except its proximal quarters. Forewing length $2.59 \mathrm{x}$ its maximum width; lower surface of costal cell with two or three short hairs, upper surface with four setae at distal part; basal cell asetose; speculum open below, extending below marginal vein, with a row of 4-5 setae below MV on lower surface if any, maximum length of marginal fringe $0.18 x$ maximum width of disc. Relative length of costal cell and veins: Costal cell - 46; MV - 32; PMV 6; STV - 9; a break present between parastigma and MV.

Gaster: In dorsal view, length 1.8x length of mesosoma, collapsed laterally; hypopygium very long, its tip situated beyond mid length of gaster (Fig. 3); ovipositor length subequal to length 

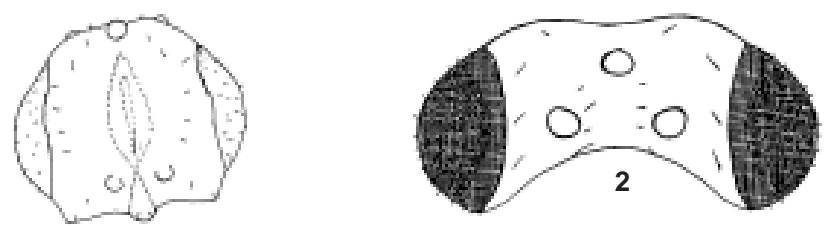

1

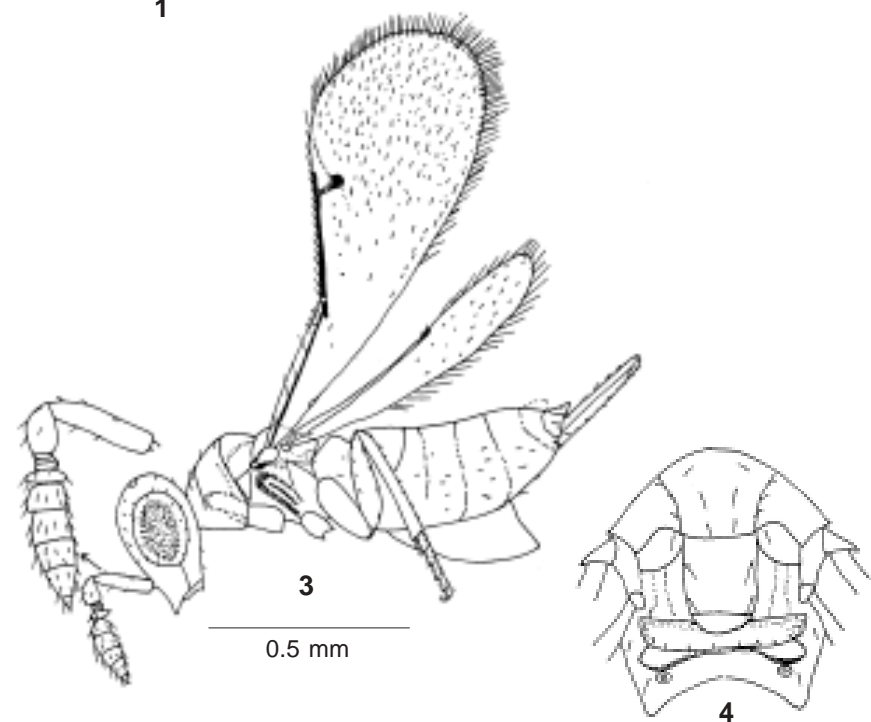

Figures 1-4. Macroglenes sivani Narendran and Sureshan, sp. nov. (Female).

1 - Head in anterior view; 2 - Head in dorsal view; 3 - Body profile; 4 - Part of mesosoma in dorsal view.

of hind tibia.

Male: Similar to female in all features except for a short gaster

Host

Unknown.

\section{Discussion}

This species differs from Macroglenes graminae Haliday in the key to species of north Western Europe by Graham (1969) but differs from it in having: (1) Exerted part of ovipositor sheaths equal or subequal to length of hind tibia (in Macroglenes graminae exerted part of ovipositor slightly more than one-third length of hind tibia); (2) F5 without distinct sensillae (in Macroglenes graminae F5 with distinct sensillae); (3) Length of clava subequal to combined length of anelli+F1+F2 (in Macroglenes graminae distinctly longer than combined length of anelli+F1+F2) and in several other features.

It does not come closer to any of the Australian species described by Girault (1925a, 1925b) under the generic name Phocion Girault which according to Boucek is a synonym of Macroglenes.

\section{Current status of habitat}

The specimens were collected from Kottiyur and Vandiperiyar forest areas (outer periphery). These areas are not found disturbed, by human interference or by any other agent.

\section{ACKNOWLEDGEMENT}

We are grateful to the Ministry of Environment and Forests, New Delhi., for financial assistance for this research. We also thank the authorities of the University of Calicut for facilities.

\section{REFERENCES}

Boucek, Z. (1988). Australasian Chalcidoidea (Hymenoptera). A Biosystematic Revision of Genera of Fourteen Families, with a Reclassification of Species. C.A.B. International, Wallingford, 832pp. Graham, M.W.R.De.V. (1969). The Pteromalidae of North Western Europe (Hymenoptera: Chalcidoidea). Bulletin of the British Museum (Natural History) Entomology (Supplement) 16: 1-908.

Girault, A.A. (1925a). Notes and descriptions of Australian Chalcid flies - III (Hymenoptera). Insecutor Inscitiae Menstruus 13: 91-100.

Girault, A.A. (1925b). Some gem-like or marvelous inhabitants of the woodlands heretofore unknown and by most never seen nor dreamt of. (Private publication), Brisbane, 3pp.

Westwood, J.O. (1832). Descriptions of several new British forms among the parasitic hymenopterous insects. London and Edinburgh Philosophical Magazine 3(1): 127-129. 